ANUVA Volume 2 (4): 429-436, 2018

Copyright @2018, ISSN: 2598-3040 online

Available Online at: http://ejournal.undip.ac.id/index.php/anuva

\title{
Dinamika Petani Kopi Lahan Terbatas di Desa Gogik Kecamatan Ungaran Barat Kabupaten Semarang
}

\author{
Af'idatul Lathifah ${ }^{*}$ ) \\ ${ }^{\text {I} P r o g r a m ~ S t u d i ~ A n t r o p o l o g i ~ S o s i a l ~ F a k u l t a s ~ I l m u ~ B u d a y a ~ U n i v e r s i t a s ~ D i p o n e g o r o, ~}$ \\ Jl. Prof, Soedarto, SH, Kampus Undip Tembalang, Semarang Indonesia \\ ${ }^{*}$ Korespondensi: afidatullathifah@gmail.com
}

\begin{abstract}
Indonesia is one of the largest coffee producers in the world. This cannot inseparable from the role of coffee farmers that spreaded throughout the region in Indonesia. However, the problem of coffee cultivation continues to emerge, reducing the quality and quantity of Indonesian coffee production. Gogik Village, Ungaran Barat Subdistrict, Semarang Regency is one of the villages that cultivates coffee as a source of their livelihood. The emergence of coffee cultivation initiated by PTPN XI triggered socio-cultural changes in the Gogik Village community, one of that was a change in land use patterns. However, various problems arise in line with the community's efforts to cultivate coffee which is actually still very young. Limited land is still surrounded by issues of conservation, land conflict, and regeneration of coffee farmers. This study uses ethnographic methods that attempt to capture the perspective of coffee farmers holistically.
\end{abstract}

Keywords: Gogik village; coffe agriculture; land tenure

\begin{abstract}
Abstrak
Indonesia adalah salah satu penghasil kopi terbesar di dunia. Hal in tentu saja tidak terlepas dari peran para petani kopi yang tersebar di seluruh wilayah di Indonesia. Akan tetapi, permasalahan pembudidayaan kopi ini terus muncul sehingga menurunkan kualitas serta kuantitas produksi kopi Indonesia. Desa Gogik Kecamatan Ungaran Barat Kabupaten Semarang adalah salah satu desa yang membudidayakan kopi sebagai salah satu sumber mata pencaharian mereka. Munculnya budidaya kopi yang diinisiasi oleh PTPN XI memicu perubahan sosial budaya di masyarakat Desa Gogik, salah satunya yaitu perubahan pola penggunaan lahan. Akan tetapi, berbagai permasalahan muncul sejalan dengan usaha masyarakat dalam membudidayakan kopi yang sebenarnya masih berumur sangat muda. Lahan yang sudah terbatas masih dilingkupi dengan persoalan konservasi, konflik tanah, hingga regenerasi petani kopi. Penelitian ini menggunakan metode etnografi yang berusaha untuk menangkap sudut pandang petani kopi secara holistik.
\end{abstract}

Kata kunci : Desa Gogik; budidaya kopi; lahan

\section{Pendahuluan}

Indonesia merupakan salah satu penghasil kopi terbesar di dunia. Indonesia mampu memasok sepertiga kebutuhan kopi dunia. Kopi masuk ke Indonesia melalui culture stetseel atau tanam paksa (1830-1870) di masa kolonial Belanda. Persebaran perkebunan kopi terbanyak ada di pulau Sumatra, Jawa, dan sebagian Indonesia Timur. Jenis kopi yang dikembangkan pada saat itu adalah kopi Arabika. Kopi Gayo dari dataran tinggi Aceh dikenal sebagai salah satu kopi terbaik di dunia. 
Di Pulau Jawa, tanaman kopi banyak dibudidayakan di dataran tinggi. Lewat tanam paksa, masyarakat menanam kopi di lahan-lahan yang pada saat itu diklaim sebagai lahan milik pemerintah Belanda. Pasca masa colonial, saat pemberlakuan undang-undang agraria banyak tanah yang diberi status sebagai tanah pemerintah (government ground). Salah satu mekanisme pemerintah untuk memberikan status pada tanah tersebut, adalah dengan memberikan hutan kepada pihak Perhutani.

Hingga saat ini, masih banyak masyarakat yang memanfaatkan tanah Perhutani untuk melakukan budidaya tanaman kopi. Salah satunya adalah budidaya kopi di Desa Gogik, Kecamatan Ungaran Barat, Kabupaten Semarang, Jawa Tengah. Artikel ini akan menguraikan tentang bagaimana petani kopi di Desa Gogik ini masih bertahan dengan budidaya kopi meski lahan yang bisa mereka tanami semakin terbatas karena pengalihan lahan menjadi lahan konservasi oleh Perhutani. Apa saja dinamika yang dialami oleh para petani kopi hingga saat ini?

Penelitian ini adalah penelitian etnografi. Peneliti tidak hanya melakukan wawancara dengan para informan tetapi juga melakukan observasi, tentunya terhadap praktek pertanian kopi yang dilakukan oleh petani kopi di Desa Gogik. Wawancara secara mendalam dilakukan untuk mendapatkan konfirmasi atas hasil observasi dan juga untuk mendapatkan informasi lain yang tidak bisa didapatkan dari observasi (Spradley: 2007).

Perubahan pola pertanian masyarakat yang disebabkab oleh masuknya komoditas baru oleh Ben White dijelaskan sebagai "agrarian diferentiation supplied" atau suplay pembeda agraris (White, 1989:20). Komoditas baru yang sebelumnya tidak mereka kenal tentu saja membutuhkan berbagai adaptasi, mulai dari pola pertanian yang berbeda, pola perawatan pertanian yang berbeda, dan tentu saja penggunaan lahan yang berbeda. Penggunaan lahan menjadi persoalan yang serius karena lahan tersebut merupakan salah satu modal produksi yang terpenting.

Penanaman kopi di Desa Gogik, Kecamatan Ungaran Barat, Kabupaten Semarang awal mulanya diperkenalkan oleh agen pemerintah, yaitu PTPN IX. Persinggungan pemerintah dan masyarakat sipil ini biasanya dalam kerangka pengurangan kemiskinan (Ferguson, 1994). Tentu saja, hal ini memberikan implikasi pada masyarakat sipil yang menjadi sasaran program. Implikasi utamanya adalah perubahan pada budaya lokal masyarakat yang menjadi sasaran. Kopi sebagai komoditas (barang yang diperjualbelikan) menggantikan pertanian subsisten, yaitu pertanian yang dilakukan hanya untuk memenuhi kebutuhan diri sendiri, sehingga kopi disebut sebagai komoditas ekonomi. Komoditas ekonomi inilah yang memungkinkan masyarakat lokal berhubungan dengan dunia global dalam kerangka ekonomi (Hart, 2007:8).

Perubahan pertanian hingga perubahan pola ekonomi ini, mendorong perubahan dalam sosial ekonomi masyarakat ( $\mathrm{Li}, 2002$ ). Li dalam penelitiannya pada masyarakat Suku Lauje di pedalaman Sulawesit Tengah menyebutkan bahwa Suku Lauje mengalami perubahan sosial karena perubahan penguasaan tanah. Pertanian coklat yang saat itu sedang menjadi tren di masyarakat karena menghasilkan uang tunai yang cukup besar, mendorong masyarakat untuk mengubah pola penguasaan tanah dan juga pandangan masyarakat mengenai pertanian. 


\section{Gogik, Desa di Kaki Gunung Ungaran}

Desa Gogik, Kecamatan Ungaran Barat, Kabupaten Semarang, Jawa Tengah terletak di kaki Gunung Ungaran. Luas keseluruhan desa ini adalah 149 hektar. Desa dengan ketinggian 800 mdpl ini memang didominasi oleh hawa dingin dan curah hujan yang cukup tinggi. Suhu rata-rata di Desa Gogik berkisar anatara 20 hingga 23 derajad celcius di musim penghujan, dan 25 hingga 28 derajad celcius di musim kemarau. Salah satu lokasi wisata yang terkenal di desa ini adalah pesona Air Terjun Semirang.

Desa Gogik berbatasan langsung dengan kawasan konservasi alam yaitu Hutan Lindung Perhutani dan Cagar Alam Jebugan. Hal ini tentu saja mempengaruhi gerak masyarakat Desa Gogik dalam memanfaatkan tanah atau kawasan hutan di sekitar desa mereka. Juka masyarakat melanggar batas, bisa jadi mereka akan mendapat masalah hukum. Untuk itu, masyarakat Desa Gogik cenderung sensitif terhadap pembahasana mengenai batas penggarapan tanah

Penduduk Desa Gogik berjumlah 843 jiwa, dengan rincian penduduk laki-laki sejumlah 330 jiwa dan penduduk perempuan sejumlah 513 jiwa. Sekitar 70\% penduduk Desa Gogik adalah petani, sekalipun demikian kegiatan bertani saat ini sudah tidak lagi menjadi mata pencaharian utama para petani tersebut. Bertani seringkali hanya menjadi usaha sampingan saja. Selebihnya para petani tersebut mengandalkan pekerjaan lainnya seperti buruh bangunan, karyawan pabrik, atau membuka warung kelontong di rumah masing-masing. Salah satu usaha yang cukup marak adalah ternak sapi perah. Para peternak sapi perah tersebut diakomodasi dengan adanya KUD Mekar yang berperan cukup siginifikan dalam pendistribusian susu sapi perah, sehingga usaha ternak ini berjalan cukup baik.

Hal di atas juga berlaku pada petani kopi. Pertanian kopi yang tidak membutuhkan perawatan yang intensif lebih mungkin dijadikan sebagai pekerjaan sampingan saja. Pemupukan kopi hanya dilakukan sekali selama satu masa panen saja. Selebihnya, petani kopi di Desa Gogik hanya sesekali menyiangi rumput yang bertumbuh di sekitar tanaman kopi mereka dan menunggu kopi tersebut hingga berbuah.

Desa Gogik juga dikenal sebagai desa yang masih menjaga ikatan sosial antar penduduk. Hal tersebut bias terlihat dari aktivitas sehari-hari yang berkaitan dengan daur hidup; kelahiran, akil baligh, perkawinan, hingga kematian. Masyarakat masih biasa bergotong royong atau rewang untuk menyambut upacara-upacara daur hidup tersebut. Sehingga setiap upacara selalu berlangsung dengan meriah.

Selain itu, masyarakat Desa Gogik juga masih melakukan ritual yang diturunkan oleh nenek moyang mereka berupa sedekah desa yang disebut sebagai Kadeso. Acara sedekah desa dimulai dengan arak-arakan masyarakat yang dimulai dari sebuah mata air di desa tersebut, lalu dilanjutkan dengan pagelaran wayang di halaman rumah kepada desa setempat. Tak lupa, pasar malam juga digelar di sepanjang jalan utama desa.

Fasilitas kesehatan dan pendidikan di Desa Gogik juga cukup memadai. Setidaknya desa tersebut memiliki satu kawasan pendidikan dasar terpadu mulai dari pendidikan kelompok bermain (KB), taman 
kanak-kanak (TK) dan sekolah dasar (TK). Sedangkan untuk sekolah lanjutan seperti SLTP dan SLTA, penduduk desa Gogik akan menempuh pendidikan tersebut di sekolah-sekolah yang juga berada di beberapa lokasi di Desa Gogik. Fasilitas kesehatan yang dimiliki adalah sebuah Puskesmas Pembantu. Akan tetapi, masyarakat lebih banyak berobat pada salah seorang bidan yang membuka praktek di sana.

Penduduk Desa Gogik juga dikenal sebagia penduduk yang religious. Sebagian besar memeluk agama Islam dan seringkali menggelar peringatan-peringatan hari besar keagamaan denga meriah. Masjid-masjdi di Desa Gogik juga dikenal oleh masyarakat sekitar sebagai masjid yang selalu meriah. Khususnya di hari Kamis malam, speaker masjid tidak lepas mengumandangkan syair-syair shalawat nabi.

Kondisi di atas mencerminkan Desa Gogik sebagai sebuah desa yang masih asri dan terjaga, baik secara ekologis maupun secara sosial. Kehidupan pedesaan yang seringkali ditemui di tanah air Indonesia ini. Akan tetapi, tentu saja modernitas juga telah menyentuh desa tersebut. Desa Gogik dicanangkan sebagai salah satu cyber village. Fasilitas internet di desa tersebut cukup memadai, sehingga para penduduk desa bias berlangganan internet dengan mudah dan murah. Para pemudanya pun mulai membangun komunitas blogger dan menampilkan desa mereka dalam setiap blog yang mereka miliki. Gaya hidup para penduduknya, khususnya para pemuda juga telah mengarah kepada gaya hidup modern yang ditandai dengan semakin canggihnya perangkat-perangkat elektronik yang mereka gunakan.

\section{Munculnya Petani Kopi di Desa Gogik}

Kopi masuk ke Desa Gogik awalnya sebagai plasma dari PTPN IX yang ada di kawasan Banaran. Lokasi Desa Gogik memang berbatasan langsung dengan PTPN IX, tepatnya di sebelah Barat desa. Petani membentuk kelompok tani plasma PTPN IX awalnya pada sekitar tahun 1996. Petani diberikan pengarahan dari pihak PTPN IX sekaligus diberikan bibit kopi yang sejenis dengan kopi yang ada di perkebunan PTPN IX. Kopi yang ditanam oleh warga Gogik adalah jenis kopi Robusta. Beberapa petani juga pada akhirnya mengembangkan kopi Luwak saat jenis kopi tersebut naik daun.

Sebagian besar kebun kopi mereka berada di tanah gege (sebutan penduduk setempat untuk tanah Perhutani atau tanah yang berstatus government ground). Tanah gege yang ditanami warga, berada di lereng-lereng Gunung Ungaran, rata-rata petani yang memiliki kebun kopi harus menempuh jarak hingga 1 kilometer untuk mencapai kebun kopi mereka. Beberapa petani yang beruntung bisa mendapatkan lahan yang dekat dengan pemukiman. "Saat itu, sistemnya diundi, PTP yang menentukan lokasi kebunnya”, terang Pak Slamet. Di sela-sela kebun kopi, petani juga menanam empon-empon sebagai tambahan penghasilan saat menunggu kopi mereka berbuah.

Masa panen pertama kali terjadi pada sekitar tahun 2000-an. Akan tetapi, panen perdana tersebut belum menghasilkan kopi yang baik, sehingga harganya pun rendah. Bahkan, beberapa pohon kopi harus ditebang karena terkena hama. Para petani saat itu tidak cukup puas dengan hasil panen mereka, sebagian bahkan mulai mengundurkan diri menjadi petani plasma, mereka memilih untuk bertani di tanah sendiri 
seperti sedia kala. Mundurnya beberapa petani kopi ini juga mendorong pihak PTPN IX untuk mencari petani lain, dan menyebar kawsan plasma mereka lebih luas hingga ke Desa Nyatnyono, sekitar 2 kilometer dari Desa Gogik.

\section{Permasalahan Budidaya Kopi; Area Konservasi, Pemukiman hingga Regenerasi Petani Kopi}

Persoalan perkebunan kopi milik penduduk Desa Gogik tidak berhenti, setelah kegagalan panen pertama muncul persoalan konversi area konservasi yang ternyata meliputi beberapa perkebunan kopi warga. Pada tahun 2001, pihak Perhutani mencanangkan area lereng Gunung Ungaran tersebut menjadi area konservasi air bagi Kabupaten Semarang. Dengan adanya kebijakan tersebut, gerak masyarakat untuk memanfaatkan area hutan Perhutani menjadi semakin terbatas. Hanya tanaman dengan kayu besar saja yang dapat ditanam di area tersebut. Dengan demikian, kopi tidak masuk menjadi salah satu tanaman yang seharusnya ditanam di area konservasi.

Pencanangan area konservasi tersebut, tentu membuat petani kopi tidak dapat mengekspansi luas perkebunan kopi mereka. Konflik tersembunyi antara pihak Perhutani dengan petani Desa Gogik pun sedikit demi sedikit mulai muncul. Petani yang merasa bahwa area tersebut sebenarnya adalah milik nenek moyang mereka, mencoba melakukan perlawanan dengan tetap mencoba memperluas area kebun kopi mereka. Sikap resistensi (Scott: 2000) tersebut juga diperlihatkan dengan upaya warga merambah area konservasi untuk kepentingan sehari-hari, seperti mencari kayu bakar untuk memasak atau memanfaatkan hasil hutan lainnya. "Semakin dilarang kan semakin ngeyel. Warga sebenarnya tidak terima kalau area ini menjadi area hutan lindung, kan ini juga tanah leluhur, kita kan setiap tahun sedekah desa ya untuk mendoakan tanah leluhur biar manfaat bagi warga. Eh kok malah dilarang dimanfaatkan", ungkap Slamet tentang kejengkelan penduduk Desa Gogik saat itu. "Perhutani saja tidak pernah kontrol disini, atau patroli, jadi warga tidak takut".

Usaha resistensi masyarakat terhadap kebijakan ini juga tercermin dari pola pikir mereka yang berusaha mengingkari pemahaman mereka sendiri tentang konsep konservasi. Orang-orang yang sudah tua masih sering memanfaatkan area konservasi untuk perkebunan mereka. Sebagian besar berpikiran, bahwa konservasi hanya diperuntukkan bagi wilayah pemukiman saja. Artinya, asalkan tidak membangun rumah di area hutan konservasi maka pemanfaatan hutan konservasi masih sah-sah saja. Padahal, pada dasarnya mereka memahami bahwa memanfaatkan hasil hutan berupa kayu jelas melanggar ketentuan konservasi, akan tetapi para penduduk tetap mencari kayu dan kadang menebang satu dua pohon untuk dijadikan kayu bakar. Hingga saat ini, penggunaan kayu bakar untuk memasak masih sangat umum dilakukan oleh penduduk Desa Gogik. Selain alasan ekonomis, alasan lainnya adalah ketakutan mereka menggunakan kompor dengan bahan bakar gas.

Selain persoalan konservasi, perambahan lahan di Desa Gogik untuk keperluan pemukiman juga semakin menyurutkan lahan perkebunan yang dimiliki. Desa Gogik ini juga merupakan salah satu desa 
yang banyak mendapatkan pendatang, bahkan dari luar daerah Ungaran. Pendatang terbanyak berasal dari Desa Boja, Kabupaten Kendal. Konon katanya, beberapa penduduk Desa Gogik memang keturunan orang Boja, sehingga lambat laun generasi-generasi selanjutnya pun mencoba mencari peruntungan di Desa Gogik. Pak Heru, salah satu perantau dari Desa Boja beranggapan, bahwa Gogik jauh lebih subur dan menjanjikan dibandingkan dengan daerah Boja, sekalipun keduanya memiliki kesamaan letak geografis. “ Di sini airnya lebih bagus, tanahnya juga lebih mudah digarap. Warna tanahnya kan pekat, berarti subur. Kalau di Boja, tanahnya merah”. Pak Heru datang ke Desa Gogik karena meminang salah satu gadis dari desa tersebut dan memutuskan tinggal di Desa Gogik dengan pertimbangan di atas.

Pendatang dari luar Desa Gogik juga banyak membangun area perumahan di desa tersebut. Komplek-komplek perumahan yang tentu saja membutuhkan lahan luas, mau tak mau menggusur area perkebunan warga. Beberapa area komplek perumahan bahkan berbatasan langsung dengan perkebunan kopi warga. Beda dengan penduduk yang menetap di perkampungan Desa Gogik, selain alasan tempat kerja, warga perumahan yang memilih tinggal di Desa Gogik seringkali tertarik pada kondisi alam Desa Gogik yang masih asri dengan sumber air yang masih berlimpah. Tentu saja, tidak seperti di perkotaan Semarang yang rawan banjir, tinggal di Desa Gogik juga merupakan salah satu cara terhindar dari persoalan banjir di masa depan. Untuk itu, tidak heran jika sebagian warga yang tinggal di komplek perumahan adalah warga yang sebelumnya tinggal di Kota Semarang.

Konflik tanah yang terjadi antar warga juga tak luput memberi pengaruh pada keberlangsungan budidaya kopi di Desa Gogik. Saling klaim antar warga terhadap petak-petak tanah tertentu mulai terjadi pada pertengahan tahun 2010. Hal tersebut dipicu oleh maraknya budidaya kayu sengon yang saat itu mulai menjadi primadona. Beberapa kebun kopi milik penduduk Desa Gogik pun nyatanya pernah diklaim oleh salah seorang pengusaha, sekalipun klaim tersebut mudah dipatahkan karena tidak adanya bukti yang memadai. Warga yang berusaha 'melindungi' petak tanah perkebunan mereka, mulai memasang spanduk atau papan dengan tulisan “ Tanah Pemerintah Bukan Tanah Perseorangan”.

Modernitas yang dibawa ke Desa Gogik juga turut mengubah pandangan masa depan generasi muda di Desa Gogik. Sebagian besar dari mereka memilih untuk menjadi karyawan pabrik daripada menjadi petani “ Anak-anak sekarang tidak bisa tandur, maunya kerja di pabrik. Lebih enak, gajinya lebih pasti. Kalau tandur kan ngga mesti juga dapat uang". Perubahan orientasi masa depan pemuda di Desa Gogik ini juga tentu mempengaruhi perkembangan pertanian di Desa Gogik.

\section{Masa Depan Budidaya Kopi di Desa Gogik}

Semakin menyempitnya lahan yang bisa digunakan untuk berkebun juga mempengaruhi produktivitas petani kopi. Perkebunan kopi tidak lagi dijalankan dengan intensif. Selain persoalan lahan, persoalan lainnya berupa konflik tersembunyi dengan Perhutani dan juga orientasi pemuda Desa Gogik turut berperan menurunkan produktivitas perkebunan kopi. 
"Sekarang kopi kami memang masih berproduksi, tetapi tidak banyak. Seadanya saja, kalau koprasi (KUD) mau membeli ya kami jual, kalau tidak ya sudah tidak usah dipanen saja". Hal ini menyebabkan sebagian besar perkebunan kopi berubah menjadi 'hutan kopi' yang tidak terawat.

Pak Slamet dan adiknya, Sugeng, biasanya hanya melihat kebun kopi mereka 1 hingga 2 minggu sekali, tergantung kesibukan mereka. Selebihnya, mereka lebih mengurus kebun palawija yang berada di dekat rumah mereka. Selain bertanam palawija, mereka juga bertanam aneka jenis bunga yang biasanya dijual di daerah Bandungan. "Lebih menguntungkan menanam bunga daripada menanam kopi", ujar Pak Sugeng.

"Untuk apa ngurusi kopi lagi, orang PTP juga sudah tidak melirik kopi kami lagi”. Kopi yang tidak memberikan keuntungan tersebut tidak lagi menjadi prioritas utama untuk digarap. Seperti pada suatu pagi, Pak Sugeng hanya sekedar melihat-lihat kebun kopinya tanpa memberikan perlakuan apapun pada kebun kopinya. Padahal tanaman kopinya sudah mulai berbunga dan bunganya pun mengeluarkan aroma wangi. Selanjutnya, Pak Sugeng pergi ke kebun bunganya dan mulai menyiangi rumput di sekitar kebun bunganya.

Kabar akan adanya peremajaan pokok kopi oleh PTPN IX pun ditanggapi dingin oleh petani. Pengalaman mereka dalam budidaya kopi sebelumnya membuat mereka tidak lagi bergairah untuk melanjutkan usaha tersebut. Kesulitan-kesulitan seringkali mereka hadapi, karena status tanah yang tidak jelas dan juga proses penjualan yang tidak pasti membuat para petani mulai apatis terhadap usaha budidaya kopi ini. Hal tersebut juga merupakan salah satu bentuk resistensi petani terhadap salah satu kebijakan pemerintah.

\section{Kesimpulan}

Budidaya kopi sebagai salah satu komoditas unggulan Indonesia ternyata tidak selalu menempuh jalan mulus. Persoalan petani di tingkat akar rumput terkadang tidak bisa dipotret secara nyata oleh pemerintah. Hal ini jika dibiarkan berlarut-larut tentu akan mempengaruhi perkembangan komoditas unggulan ini. Permasalahan yang dihadapi petani kopi di Desa Gogik juga cukup pelik. Lahan yang sejak semula sudah terbatas, saat ini harus menghadapi berbagai hantaman permasalahan lainnya, berupa perubahan status lahan, konflik kepentingan atas lahan tertentu, desakan pemukiman warga, dan orientasi masa depan generasi penerus petani. Untuk itu, diperlukan usaha yang lebih serius dari pemerintah dan sinergitas antar lembaga pemerintah, khususnya PTPN IX dan Perhutani agar dapat terus mendukung budidaya kopi. Sehingga ikon Indonesia sebagai penghasil kopi tidak tergusur dan tentu saja kesejahteraan petani kopi dapat ditingkatkan. 


\section{Daftar Pustaka}

Ferguson, B. 1994. The Anti-politics M achine: "D evelopment", Depoliticization and Bureaucratic Power in Lesotho. Minneapolis: University of Minnesota Press

Hart, Keith. 2007. The Political Economy of West African Agriculture. Cambridge: Cambridge University Press

Li, Tania. 2002. Local Histories, Global Market: Cocoa and Calss in Upland Sulawesi. dalam Development and Change 33 (3). 415-437. Oxford: Blackwell Publishers

Scott, James. C. 2000. Senjatanya Orang-orang Kalah. Jakarta: Yayasan Obor Indonesia

Spradley, James. 2007. Metode Penelitian Etnografi. Jakarta: Tiara Wacana

White, B. (1989) 'Problems in the Empirical Analysis of Agrarian Differentiation', in G. Hart, A. Turton and B. White (eds) Agrarian Transformations: Local Processes and the State in Southeast Asia, pp. $15 \pm 30$. Berkeley, CA: University of California Press. 